
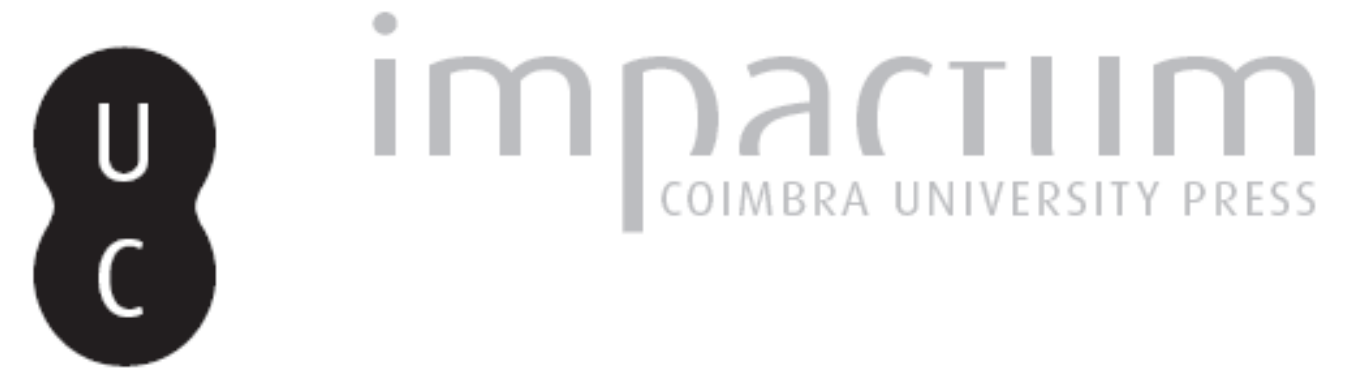

\title{
No centenário do nascimento do Doutor José Joaquim Teixeira Ribeiro
}

Autor(es): $\quad$ Basto, José Guilherme Xavier de

Publicado por: Faculdade de Direito da Universidade de Coimbra

URL persistente:

URI:http://hdl.handle.net/10316.2/24743

DOI:

http://dx.doi.org/10.14195/0870-4260_51_1

Accessed : $\quad$ 26-Apr-2023 07:09:17

A navegação consulta e descarregamento dos títulos inseridos nas Bibliotecas Digitais UC Digitalis, UC Pombalina e UC Impactum, pressupõem a aceitação plena e sem reservas dos Termos e Condições de Uso destas Bibliotecas Digitais, disponíveis em https://digitalis.uc.pt/pt-pt/termos.

Conforme exposto nos referidos Termos e Condições de Uso, o descarregamento de títulos de acesso restrito requer uma licença válida de autorização devendo o utilizador aceder ao(s) documento(s) a partir de um endereço de IP da instituição detentora da supramencionada licença.

Ao utilizador é apenas permitido o descarregamento para uso pessoal, pelo que o emprego do(s) título(s) descarregado(s) para outro fim, designadamente comercial, carece de autorização do respetivo autor ou editor da obra.

Na medida em que todas as obras da UC Digitalis se encontram protegidas pelo Código do Direito de Autor e Direitos Conexos e demais legislação aplicável, toda a cópia, parcial ou total, deste documento, nos casos em que é legalmente admitida, deverá conter ou fazer-se acompanhar por este aviso.

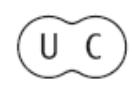




\section{UNIVERSIDADE DE COIMBRA \\ FACULDADE DE DIREITO}

BOLETIII DE CÊACCLS ECONÓNCACAS

VOLUME LI

$\begin{array}{llll}2 & 0 & 0 & 8\end{array}$

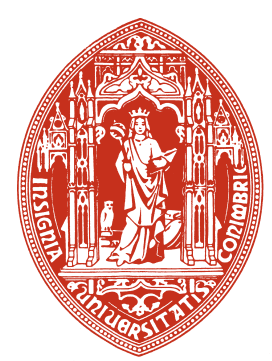

COIMBRA 


\section{NO CENTENÁRIO DO NASCIMENTO DO DOUTOR JOSÉ JOAQUIM TEIXEIRA RIBEIRO}

Quis o Boletim de Ciências Económicas, pela voz do seu Director, o Doutor António José Avelãs Nunes, honrar-me com a solicitação para assinalar, nestas páginas, a passagem do centenário do nascimento do Doutor José Joaquim Teixeira Ribeiro, ocorrida a 4 de Outubro de 2008.

O Doutor José Ribeiro, como muitos do meu tempo e de tempos anteriores, o conheciam - foi o Mestre incomparável de tantas gerações de estudantes da Faculdade de Direito de Coimbra. A sua obra científica e as suas virtudes cívicas e académicas já foram amplamente tratadas nas páginas do Boletim da Faculdade de Direito. Aquando da sua jubilação, em 1978, seguindo a estranha tradição da Faculdade de Direito da Universidade de Coimbra, que quer que seja um discípulo do Mestre que profira, em vez deste, a última lição, a que aliás o homenageado não deve assistir, o Doutor Manuel Carlos Lopes Porto traçou o perfil científico do Doutor José Ribeiro, nos domínios da Economia Política, das Finanças Públicas e do Direito Fiscal, a par da sua obra de reformador do sistema fiscal português.

Em comovida oração, pronunciada aquando das suas exéquias fúnebres, o Doutor António José Avelãs Nunes, à época Presidente do Conselho Directivo da Faculdade de 
Direito e também seu discípulo, evocou a carreira do grande Professor e do cidadão empenhado num período conturbado e rico, em acontecimentos e ideias, da nossa história recente.

Passados já 14 anos sobre a sua morte, aos 86 anos de vida de trabalho e empenhamento no ensino e na investigação, acalmado o sentimento de perda que todos os que lhe éramos mais próximos experimentámos com o seu desaparecimento, será o tempo de recordar o professor quotidiano, mais que o cientista, o homem privado, mais que o homem público.

Professor à moda antiga de Coimbra, com os seus rituais sóbrios, mas rigorosamente cumpridos, Teixeira Ribeiro não era, por natureza, pessoa que demonstrasse facilmente os seus afectos, ou com quem fosse fácil criar intimidade. Mantinha alguma distância, o que não impedia uma grande atenção e solicitude no atendimento dos estudantes e dos discípulos.

Praticou sempre o ritual coimbrão das aulas magistrais. Entrava e saía da sala de aula em último lugar. Pontualíssimo no início da aula (pontualíssimo em tudo...), era-o também no final: a exposição terminava ao toque da hora na velha "cabra" da torre da Universidade. E terminava onde tinha de terminar, tão bem calculado era o tempo da prelecção.

Vivia intensamente a actividade docente. Lembro-me bem da sua primeira aula, de Finanças Públicas, ao meu curso jurídico de 1955-60, no Outono de 1958. As suas principais preocupações iriam ser, como nos disse - e são palavras textuais - "ser claro na exposição e justo nos exames”. Preocupações muito genuinamente sentidas e, podemos mesmo dizê-lo, intensamente sofridas.

A clareza da exposição - quer oral, quer escrita - sempre foi um dos traços mais marcantes da sua personalidade de Professor. Começava logo pela apresentação escrita - a 
giz, na lousa, como é óbvio - do sumário da Lição, numa letra pequena, certa, quase geométrica, que aliás manteve até ao fim da vida. Apesar de não ser dotado de boa voz, sabia fazer-se ouvir por toda a turma, o que não era, nem é, tarefa fácil nas caprichosas condições acústicas das salas dos Gerais. E o discurso vinha sempre de meridiana clareza, seguindo de perto, sem todavia as ler, as suas Lições escritas, que foram, e são, modelos pedagógicos com provas dadas a sucessivas gerações de estudantes de Economia e de Finanças Públicas, na Faculdade de Direito de Coimbra e em outras Escolas Superiores do nosso País.

Essa clareza de exposição só era conseguida com um empenhado e sistemático labor na escolha atormentada da palavra ou das palavras exactas que exprimissem claramente o seu pensamento. Seguia à risca o verso de Boileau: "ce que l'on conçoit bien, s'exprime clairement..." Detestava as formulações aproximativas, que não fossem à prova das regras da lógica formal, que se pudessem prestar à confusão e ao equívoco. Usava frequentemente, como crítica a quem não conseguisse definir com exactidão uma ideia, a expressão francesa "à peu près": saber as coisas à peu près...queria dizer...não as saber bem. Alguma dessa intransigência para com a expressão obscura e não rigorosa era por vezes caricaturada pelos estudantes, correndo a lenda de que exigia tudo ipsis verbis, à moda dos lentes de Coimbra que Eça de Queiroz tanto ironizou. Não era assim, todavia. Acontecia apenas que muitas das suas formulações estavam, como hoje se diria, optimizadas - e era difícil ao estudante encontrar para elas alternativas válidas...

Aliás, a exigência começava consigo próprio e exprimia-se na insatisfação perante os seus próprios escritos. Só isso explica que as suas Lições de Finanças Públicas viessem a ser publicadas em "veste tipográfica" - para citar as suas próprias palavras, na $1^{\text {a }}$ edição da obra - em 1977, ou seja, a 
um ano da sua jubilação. Circulavam, em outra veste, pelo menos desde 1958, e eram adoptadas em outras escolas superiores como manual, sempre admiradas pela clareza da exposição e pela profundidade no tratamento de muitos temas árduos do Direito Financeiro e da ciência das Finanças Públicas. Tiveram cinco edições, com tiragens significativas para o mercado português de obras do género, todas, excepto a quarta, refundidas e enriquecidas com o produto da investigação e do intenso estudo a que sempre se dedicou. Embora, no prefácio da $1^{a}$ edição, mostrasse, com verdadeira mas desajustada modéstia, que considerava as Lições obra insatisfatória - "...estas lições sempre valem alguma coisa, embora pouco..." - não deixou de sentir orgulho, e manifestá-lo, perante o indiscutível sucesso da obra, no plano editorial. No prefácio da $3^{a}$ edição, de 1989 , dá-se conta, agradado, mas não envaidecido, de "ter o livro continuado a merecer o favor do público estudantil”. E, no prefácio da última edição, de Novembro de 1994, sob o "peso dos anos", fala mesmo do "êxito do livro", que, já evidente na $2^{a}$ edição, aí atribuíra, com notável clarividência, a três atributos fundamentais: "a clareza, a concisão e a formatividade".

São, com efeito, essas as propriedades das Lições que fizeram delas um texto didáctico inestimável.

Clareza e concisão, que são afinal duas faces do mesmo processo pedagógico: tornar o texto "acessível ao aluno médio", "não gastar palavras supérfluas ao entendimento delas", nem "fazer desenvolvimentos dispensáveis". E ainda, "predomínio da formação, sobre a informação, reduzindo esta ao estritamente necessário...".

Trata-se, com efeito, de um manual formativo, muito mais do que informativo. Por isso é que, embora vários dos capítulos do livro, em especial o referente à dívida pública, estejam hoje superados pela vertiginosa evolução dos factos económicos, continua a valer a pena ler a lição do Mestre, 
não tanto pela informação nela contida, mas muito pela forma como é apresentada, pelo método discursivo e explicativo por ele seguido. Um método que afinal forma a mente para a compreensão dos fenómenos sociais, familiariza o leitor com formulações exactas e não aproximativas ou obscuras. Um método que, idealmente, como o exprimiu com saudável ingenuidade, no prefácio da $2^{\mathrm{a}}$ edição, habilite os alunos "a compreender, mais do que a realidade das finanças dos países capitalistas em determinada época, a realidade das finanças desses países em todas as épocas”.

Queria também ser justo nos exames. Os exames constituíam para o Doutor Ribeiro uma inquietação e um desassossego, que sempre se me afigurou dificil de compreender, na dimensão de "sofrimento" que lhe provocavam. E não se eximiu a ser também examinador praticamente até ao fim da sua carreira de professor, quer nas provas escritas, quer nas provas orais. Testemunhei directamente a preocupação de rigor com que classificava as provas escritas, preocupado com a justiça relativa, comparando respostas, torturado com a possibilidade de cometer alguma desigualdade de tratamento. Certamente as cometia, como não pode deixar de acontecer a quem julga, mas não por falta de apreciação aturada das provas, ou de ponderação dos critérios. Eram os exames um período do ano lectivo que lhe trazia tensão desproporcionada. O seu sentido do dever e o rigor que exigia de si mesmo não lhe permitiam uma abordagem mais distendida a essa outra, menos interessante, função de professor.

Terá sido Teixeira Ribeiro um professor realizado? Rigoroso e exigente como era, estou convencido de que nunca se terá sentido integralmente satisfeito com os resultados do seu labor. Foi, sem dúvida, um grande Professor, daqueles que deixam marca nos seus alunos e nos seus 
discípulos. Mais pela forma como ensina, como expõe, como escreve, do que pelo conteúdo do próprio ensino. Este pode já estar em larga medida esquecido, mas ficaram na memória as noções fundamentais. E os que o ouviram e o leram, com a atenção devida, cultivarão sempre o gosto pelo pensamento claro e ordenado, pela lógica rigorosa do raciocínio, pela limpidez da escrita. É esse o grande legado do Doutor Ribeiro. E esse legado é afinal a prova provada de que atingiu o seu objectivo de Professor, tal como o exprimiu na dedicatória única das suas Lições: "Aos que foram meus alunos e levaram consigo, no espírito ou no coração, algo de mim”.

Coimbra, Dezembro de 2008

José Guilherme Xavier de Basto 